\title{
Seasonal and interannual dynamics of diatom assemblages in Sacrower See (NE Germany): a sediment trap study
}

\author{
E. P. Kirilova $\cdot$ P. Bluszcz $\cdot$ O. Heiri $\cdot$ H. Cremer $\cdot$ C. Ohlendorf $\cdot$ \\ A. F. Lotter $\cdot$ B. Zolitschka
}

Received: 17 December 2007 / Revised: 26 May 2008/Accepted: 9 June 2008/Published online: 29 June 2008

(C) The Author(s) 2008

\begin{abstract}
Diatom assemblages from sediment trap samples collected during ten intervals between October 2003 and October 2005 in Sacrower See (NE Germany) were related to limnological and meteorological data. Sacrower See is a dimictic, $38 \mathrm{~m}$ deep, hypertrophic lowland lake (29.5 m a.s.l.). We identified distinct seasonal and interannual changes of diatom assemblages for the studied period. Diatoms showed a typical seasonal succession for temperate, dimictic, and eutrophic lakes. Stephanodiscus parvus, S. hantzschii, S. neoastraea, and S. alpinus had high accumulation rates during winter and spring, whereas species of the genera Stephanodiscus, Fragilaria, and Nitzschia were the predominant diatoms during summer and autumn.
\end{abstract}

Handling editor: J. Saros

E. P. Kirilova $(\square) \cdot$ O. Heiri · A. F. Lotter

Palaeoecology, Institute of Environmental Biology, Utrecht University, Laboratory of Palaeobotany and Palynology,

Budapestlaan 4, 3584 CD Utrecht, The Netherlands

e-mail: e.p.kirilova@uu.nl

P. Bluszcz · C. Ohlendorf · B. Zolitschka

Geopolar, Geomorphology and Polar Research, Institute for Geography, University of Bremen, Celsiusstr. FVG-M, 28359 Bremen, Germany

\section{H. Cremer}

Netherlands Organization for Applied Scientific Research TNO, National Geological Survey, Princetonlaan 6, 3584 CB Utrecht, The Netherlands
In a Canonical Correspondence Analysis, precipitation, air and water temperatures, epilimnetic calcium, $\mathrm{pH}$, and total phosphorus concentrations together explained $70 \%$ of the variance of the diatom data. Interannual variability in the diatom assemblages during the two sampled years mainly seems to reflect changes in the total phosphorus concentration and temperature and secondarily the onset of the growing season and of stratification.

Keywords Sediment traps - Diatom seasonality Phosphorus - Climate

\section{Introduction}

Diatoms are excellent indicator organisms for assessing the state of lake ecosystems. Since their valves preserve well in sediments, they are useful proxies for reconstructing past changes in lake water chemistry. Diatoms are sensitive to lake water $\mathrm{pH}$, nutrient concentrations, and salinity (Stoermer \& Smol, 1999; Battarbee et al., 2001, and references therein). Different phases of the annual cycle in a lake are characterized by diatoms preserved in sediments and fossil diatom assemblages, thus, reflect seasonal changes in sedimentation (Sommer, 1986; Stoermer, 1993). Hence, diatoms in lake sediments cannot only be used to reconstruct past water column characteristics but they may also provide important 
information about the formation of seasonal sediment layers, which themselves can play a key role for dating lacustrine sediments (Lotter \& Birks, 1997; Zolitschka, 2003).

In the past decades, interest in the use of diatoms as indicators of water quality has grown (e.g. Hall et al., 1999; Birks et al., 2004; Clarke et al., 2005; Blass et al., 2007; Bennion \& Battarbee, 2007). A controversial aspect in this discussion is the role of direct and indirect effects of environmental and climatic changes on diatoms. The determination of the seasonal variability of different abiotic factors in lakes and the response of diatoms to these changes gives essential information for the interpretation of palaeoecological reconstructions (Kilham et al., 1996; Hausmann \& Pienitz, 2007) and about the role of direct versus indirect effects on diatom assemblages (Anderson, 2000).

Sediment trap studies provide modern autecological information on diatoms and hence permit more reliable interpretations of sedimentary diatom assemblages (Battarbee et al., 2005). Seasonal changes in the composition of diatom communities have been studied in mountain or arctic lakes where the duration of ice cover may play an important role for the development of the diatom flora (Lotter \& Bigler, 2000). Hausmann \& Pienitz (2007) show a strong impact of spring and summer conditions on diatom assemblages collected in sediment traps from various Canadian lakes. This suggests that on short time scales the response of diatom communities to seasonal temperature variations may be more prominent than the forcing by mean annual temperatures. Other studies focused on the annual succession of diatoms in dimictic lowland lakes (Raubitschek et al., 1999; Schönfelder et al., 2002; Köster \& Pienitz, 2006). These studies demonstrate that the seasonal succession of diatoms differs among lakes depending on factors, such as stratification, temperature, nutrients, $\mathrm{pH}$, oxygen saturation, dissolved iron and calcium, maximum water depth, and dissolved organic carbon.

We studied the interannual and seasonal variability of diatom accumulation rates and their relationship to physico-chemical conditions in Sacrower See, northeastern Germany. The two year period of investigation covered the major fluctuations in the physico-chemical parameters and diatom assemblages in this hypertrophic, deep lake. The goal of this study is to compile information on the phenology of different diatoms in relation to limnological and meteorological parameters as well as to provide a sound basis for the interpretation of the lake's sedimentary diatom record.

\section{Study site}

Sacrower See $\left(13.06^{\circ} \mathrm{E}, 52.27^{\circ} \mathrm{N}\right)$ is a lowland lake located at an elevation of $29.5 \mathrm{~m}$ a.s.l. between Berlin and Potsdam, northeastern Germany (Fig. 1). The $2.7 \mathrm{~km}$ long lake is subdivided into three basins that are separated by shallow sills. Sacrower See is connected with Groß Glienicker See in the northeast and with the river Havel in the south. It is a hypertrophic hardwater lake with a maximum water depth of $38 \mathrm{~m}$. The catchment area of $35.3 \mathrm{~km}^{2}$ is mainly covered by deciduous and coniferous forests. Detailed hydrological, geochemical, sedimentological, and geographical characteristics of Sacrower See are presented by Lüder et al. (2006) and Bluszcz et al. (2008).

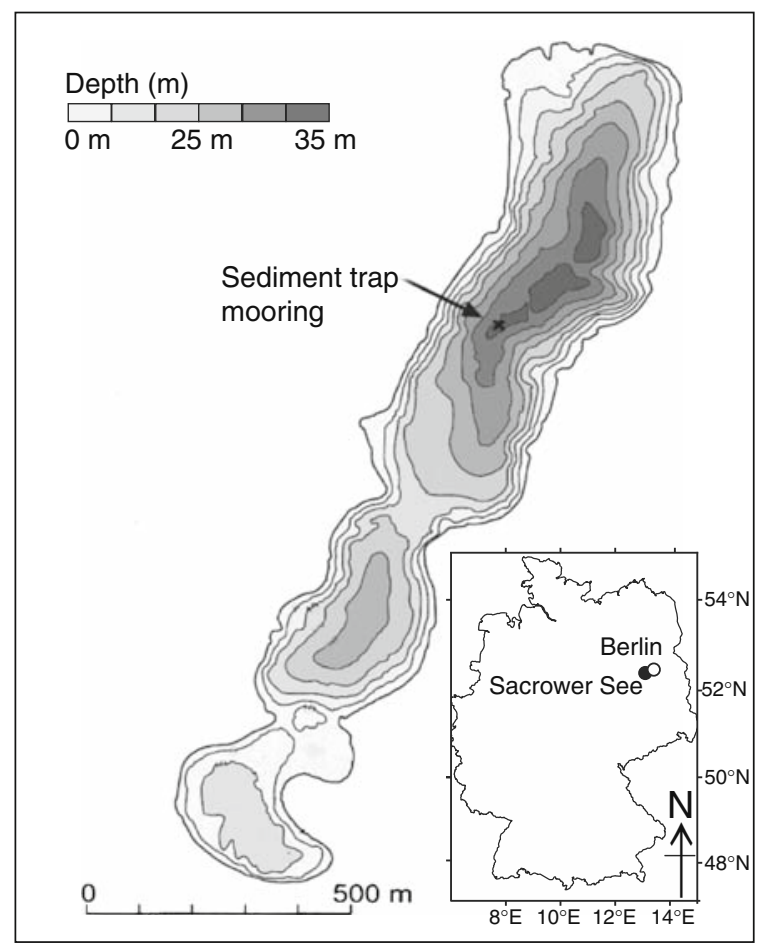

Fig. 1 Location and bathymetry of Sacrower See (northeastern Germany). Position of the mooring in the northern lake basin is indicated 


\section{Methods}

A mooring with different sediment traps and temperature sensors was deployed between October 2003 and October 2005 (Fig. 1). The sediment traps are integrating traps, each made of two parallel transparent, $650 \mathrm{~mm}$ long PVC tubes with total active area of $57 \mathrm{~cm}^{2}$. The sediment traps were moored at the deepest part of the northern basin at water depths of $5,13,20,25,30$, and $33 \mathrm{~m}$. The exposure time of the traps was between 47 and 131 days. Sampling intervals were irregular due to logistic reasons. A description of the sediment trap setup and the hydrochemical results is provided by Bluszcz et al. (2008). For this study, we analyzed the diatom assemblages at $33 \mathrm{~m}$ water depth, because this depth represents the most integrated assemblages from the littoral and the pelagic part of the lake. Furthermore, the deepest trap provides the most useful information about diatom assemblages deposited in the sediments. Monthly water chemistry and physical data were obtained from the Landesumweltamt Brandenburg (Table 1). Measurements include dissolved calcium, potassium, iron, silica, alkalinity, oxygen, total phosphorus (TP), total nitrogen, ortho-phosphate $\left(\mathrm{PO}_{4}{ }^{3-}\right)$, transparency, $\mathrm{pH}$, biochemical oxygen demand (BOD), total organic carbon (TOC), water temperature, and redox potential. All parameters were measured according to the corresponding DIN (Deutsche Industrie Norm) standard. Data on precipitation (PP), air temperature, and sunshine duration were obtained from the meteorological station Potsdam.

Detailed water chemistry data were available for 11 dates per year. In order to allow a comparison with the time intervals covered by the sediment traps, the water chemistry data for each individual day of the campaign were interpolated between the 11 measured water chemistry sampling dates. The water chemistry value for a given sediment trap interval was then considered to be equivalent to the mean of these calculated values averaged over all study days encompassed in the interval (Fig. 2). TP concentrations were not recorded for the period May 26 to July 15, 2004. However, an estimate of TP for this period was calculated based on the strong linear relationship between $\mathrm{PO}_{4}{ }^{3-}$ and TP in the remaining water chemistry measurements $\left(\mathrm{TP}=1.37 \times 0.22 \quad\left(\mathrm{PO}_{4}{ }^{3-}\right)+0.017 ; \quad r^{2}=0.79\right)$.
Table 1 Summary of major physico-chemical variables of Sacrower See (Lüder et al., 2006, Bluszcz et al., 2008)

\begin{tabular}{|c|c|}
\hline Parameter & Value \\
\hline Altitude & $29.5 \mathrm{~m}$ a.s.l. \\
\hline Catchment area & $35.3 \mathrm{~km}^{2}$ \\
\hline Surface area & $1.07 \mathrm{~km}^{2}$ \\
\hline Volume & $19.3 * 10^{6} \mathrm{~m}^{3}$ \\
\hline Maximum depth & $38 \mathrm{~m}$ \\
\hline Mean depth & $18 \mathrm{~m}$ \\
\hline Minimum width & $250 \mathrm{~m}$ \\
\hline Maximum width & $500 \mathrm{~m}$ \\
\hline Typical epilimnion depth & $7 \mathrm{~m}$ \\
\hline Water residence time & $12-15$ years \\
\hline Typical stratification period & Apr-Nov \\
\hline Annual precipitation & $603 \mathrm{~mm}$ \\
\hline Summer $T_{\text {water }}$ down to $5 \mathrm{~m}$ & $15-20^{\circ} \mathrm{C}$ \\
\hline Winter $T$ water down to $5 \mathrm{~m}$ & $1-2^{\circ} \mathrm{C}$ \\
\hline $\mathrm{pH}$ & $7-9$ \\
\hline Epilimnetic $\mathrm{PO}_{4}{ }^{3-}$ & $0.01-0.9 \mathrm{mg} \mathrm{l}^{-1}$ \\
\hline Hypolimnetic $\mathrm{PO}_{4}{ }^{3-}$ & $0.6-4.6 \mathrm{mg} \mathrm{l}^{-1}$ \\
\hline Epilimnetic $\mathrm{NO}_{3}^{-}$ & $0.01-0.7 \mathrm{mg}^{-1}$ \\
\hline Hypolimnetic $\mathrm{NO}_{3}{ }^{-}$ & $30 \mathrm{mg} \mathrm{l}^{-1}$ \\
\hline Total phosphorus & $0.02-0.16 \mathrm{mg} \mathrm{l}^{-1}$ \\
\hline $\mathrm{SiO}_{2}$ & $0.05-0.42 \mathrm{mg} \mathrm{l}^{-1}$ \\
\hline
\end{tabular}

For the comparison between limnological and diatom data, only the average water chemistry data of the measurements obtained between 0 and $5 \mathrm{~m}$ water depth were used since these were considered to be most representative for the photic zone.

Relationships between relative diatom abundance and environmental factors were assessed using multivariate statistical methods as implemented in the software CANOCO 4.51 (ter Braak \& Šmilauer, 1998). Detrended correspondence analysis (DCA) showed a gradient length of 2.5 standard deviation units (SD) in the diatom assemblages. Therefore, the relationship between the diatoms in the sediment traps and the environmental factors was assessed using canonical correspondence analysis (CCA) which is based on a unimodal species response model. The percentage of variance explained by each of the included environmental parameters was individually calculated by a CCA with the respective parameter as the only environmental variable 

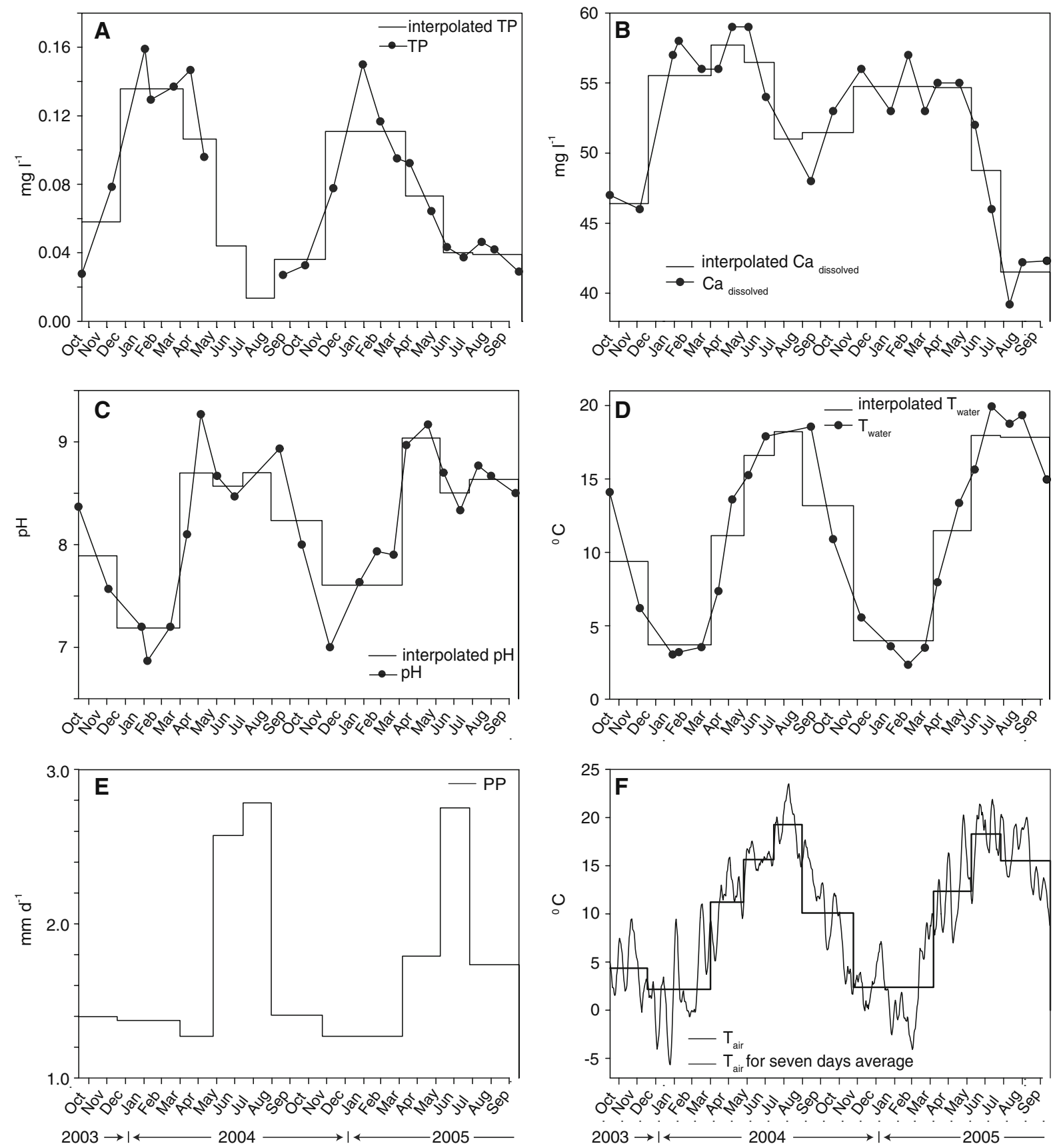

Fig. 2 Selected environmental parameters in the euphotic zone $(0-5 \mathrm{~m})$ of Sacrower See (A-D) interpolated for the sediment trap intervals (solid lines; for details see text) and as measured during the sampling campaign (dotted lines). Meteorological data $(\mathbf{E}, \mathbf{F})$ were recorded at the meteorological

included in the analysis. Principal component analysis (PCA) was used to assess the relationship among different environmental parameters.

station Potsdam. The high resolution data of air temperatures presented in $\mathrm{F}$ are 7-day running means of daily temperature readings. See Table 2 for abbreviations used for the environmental parameters

Samples from the sediment traps were treated with hydrogen peroxide in order to dissolve all organic matter. Diatom slides were prepared with the 
sedimentation tray method (Battarbee, 1973) and Naphrax ${ }^{\circledR}$ was used as mounting medium. Between 300 and 500, valves were counted on random transects at $1000 \times$ magnification using an Olympus BX51 microscope equipped with an oil immersion objective and differential interference contrast. Additionally, scanning electron microscopy (Philips XL30S FEG) was performed to confirm the identity of taxonomically problematic diatoms. Diatom identification follows Krammer \& Lange-Bertalot (1991, 1999a, b, 2000), Håkansson (2002), and, for the new genera of the genus Fragilaria, Compère (2001) and Round et al. (1990).

\section{Results and discussion}

Environmental parameters

Air and water temperatures at Sacrower See show a distinct annual cycle (Fig. 2) and are highly correlated, as expected for mid-latitude lowland lakes (e.g. Livingstone \& Lotter, 1998). The lowest air and water temperature, $\mathrm{pH}$, and precipitation values were recorded between December 2003 and April 2004, as well as between November 2004 and April 2005. In contrast, TP concentration was highest during the winter months. Ca concentrations exhibit maximum values from April to May 2004 and from November 2004 to April 2005 (Fig. 2).

The stratification period of Sacrower See lasted from mid-April to mid-October in both 2004 and 2005 with a thermocline located between 6 and $8 \mathrm{~m}$ water depth. The growing season (the period when daily air temperatures continually exceeded $5^{\circ} \mathrm{C}$, see e.g. Menzel et al., 2003) started in April 2004 and in March 2005.

A PCA was used to summarize relationships among the different measured environmental parameters (Fig. 3). As expected over the course of two seasonal cycles, most environmental parameters were strongly correlated with climatic parameters. TOC and $\mathrm{pH}$ show a strong positive correlation with temperature, whereas parameters such as $\mathrm{TP}, \mathrm{TN}$, $\mathrm{PO}_{4}{ }^{3-}, \mathrm{SiO}_{2}$, water transparency, and alkalinity are negatively correlated. Only parameters such as $\mathrm{Ca}$, BOD, $\mathrm{O}_{2}$, and Fe show a relatively weak relationship with climatic parameters.

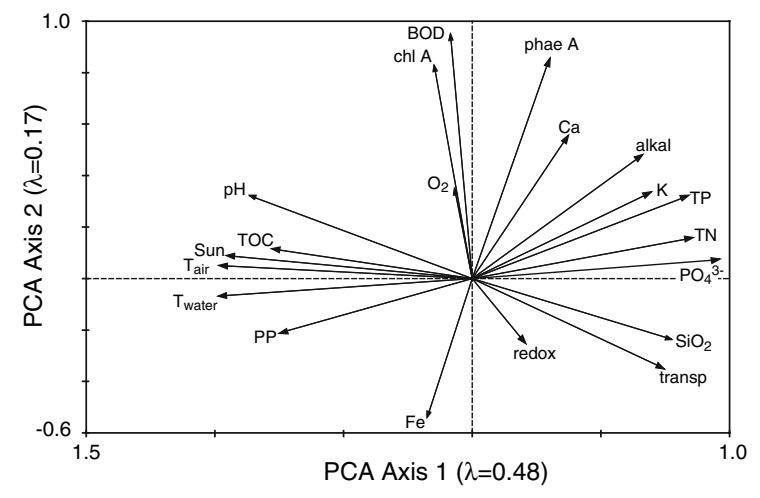

Fig. 3 PCA analysis of environmental parameters measured at Sacrower See. See Table 2 for abbreviations used for the environmental parameters

\section{Diatom assemblages}

Diatoms identified in the sediment traps are typical for eutrophic and hypertrophic lakes and include species such as Stephanodiscus parvus, S. neoastraea, S. hantzschii, S. alpinus, Ulnaria ulna, Fragilaria delicatissima, F. crotonensis, F. capucina, and Epithemia sorex. Diatom accumulation rates (AR) varied considerably during the study period (Fig. 4). The highest AR were registered in spring, when species of Stephanodiscus dominated assemblages. During the rest of the year, AR were lower and assemblages showed a higher proportion of benthic and tychoplanktic diatoms.

In order to assess the strength of the relationship of the environmental parameters with the diatom assemblages, we calculated a series of CCAs with only a single environmental parameter included. Of these analyses the CCAs with $\mathrm{Ca}$, alkalinity, and $\mathrm{K}$ as sole explanatory variables had $P$-values of 0.1 (Table 2), which is the minimum value that can be obtained with permutations tests based on our 10 samples. Similarly, the calculated $P$-values of the remaining parameters $(0.26-0.90)$ were not significant. This absence of significant relationships is due to the low number of analyzed samples rather than to a lack of relationships between environmental parameters and diatom assemblages. The parameters individually explained between 6.9 and $16.9 \%$ of the variance in the diatom assemblages (Table 2), with $\mathrm{Ca}$, alkalinity, and $\mathrm{K}$ explaining the highest amount of the observed variance $(16.2-16.9 \%)$. 
Fig. 4 Accumulation rates (AR) of the most frequent diatom taxa recorded in the sediment traps between October 2003 and October 2005

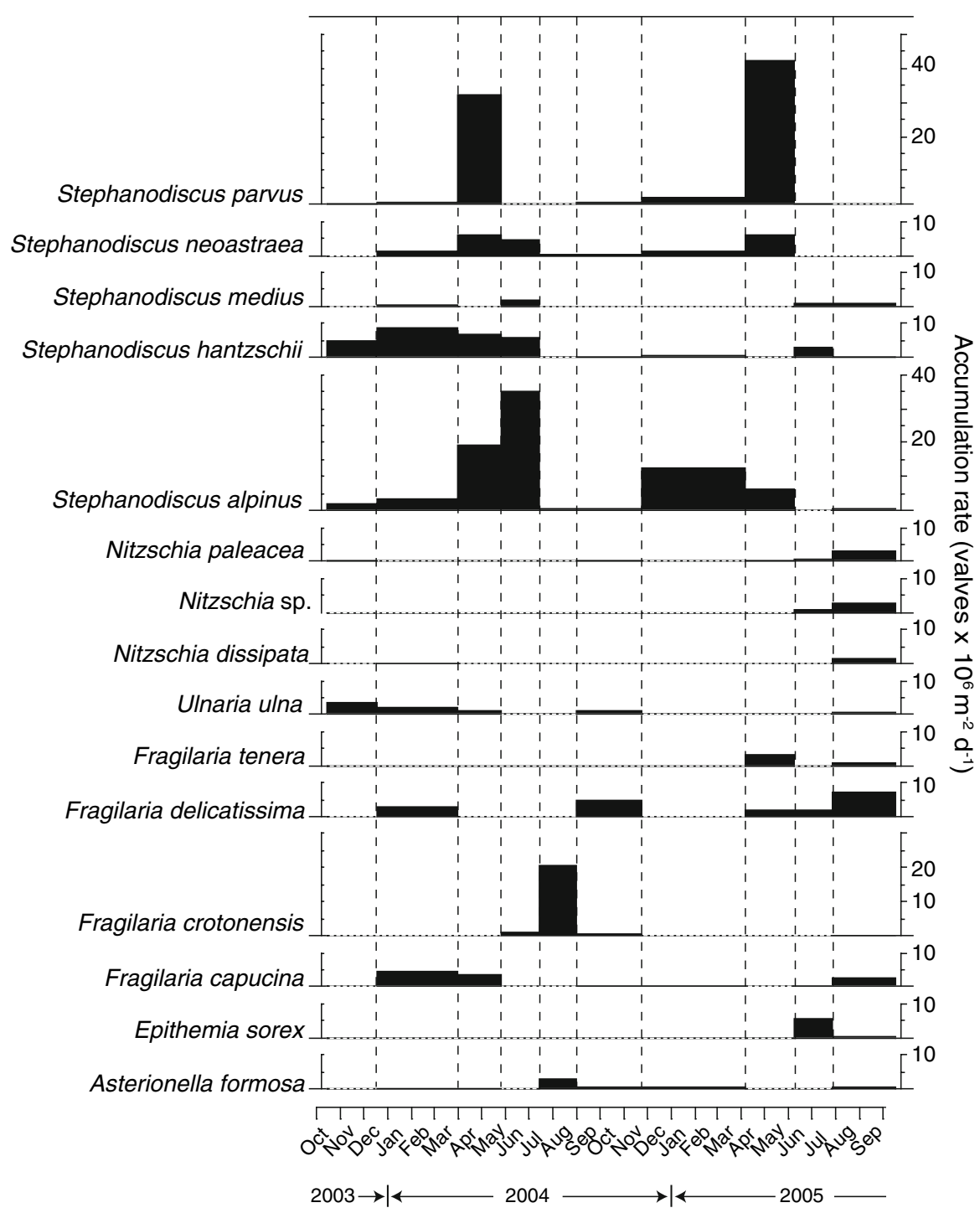

The PCA indicates that parameters that explained a high proportion of variance in the diatom data were closely correlated (Fig. 3). Air and water temperatures were positively correlated to light intensity (sun), $\mathrm{pH}, \mathrm{TOC}$, and $\mathrm{PP}$ and negatively correlated to $\mathrm{PO}_{4}{ }^{3-}, \mathrm{TP}, \mathrm{K}$, and alkalinity.

We selected the water chemistry variables $\mathrm{pH}, \mathrm{Ca}$, and TP to be further used in a CCA of the diatom assemblages with several environmental parameters included simultaneously. Ca explains the highest proportion of variance if used as a single explanatory variable (Table 2). $\mathrm{pH}$ and TP have been reported to exhibit a strong influence on diatom assemblages and are of interest for the reconstruction of past $\mathrm{pH}$ and TP changes based on fossil diatom assemblages. Furthermore, we also included $T_{\text {air }}, T_{\text {water, }}$ and PP in the analysis. Temperature is an important determinant for seasonal changes in lake ecosystems, influencing physiological factors, such as growth rates of organisms, and seasonal stratification of the water column. $\mathrm{PP}$ is a second environmental parameter reflecting seasonal climatic change and can have a strong influence on sedimentary processes in hardwater lakes (Lotter \& Birks, 1997). Furthermore, catchment runoff during high PP events is a potential mechanism for transporting nutrients to the lake during the summer stratification period. $\mathrm{Si}$, an important nutrient for diatom growth, was not included in the CCA, since 
Table 2 Explained variance $(\%)$ and significance of analyzed environmental parameters from Sacrower See. Variance and significance are calculated by CCAs with a single explanatory variable and by Monte Carlo permutation tests (999 restricted permutations)

\begin{tabular}{|c|c|c|c|}
\hline Name & Parameter & $P$-value & $\%$ variance explained \\
\hline Dissolved calcium $\left(\mathrm{mg}^{-1}\right)$ & $\mathrm{Ca}$ & 0.10 & 16.9 \\
\hline Alkalinity $\left(\mathrm{mmol} \mathrm{l}^{-1}\right)$ & alkal & 0.10 & 16.3 \\
\hline Dissolved potassium $\left(\mathrm{mg}^{-1}\right)$ & K & 0.10 & 16.2 \\
\hline Oxygen $\left(\mathrm{mg} \mathrm{l}^{-1}\right)$ & $\mathrm{O}_{2}$ & 0.26 & 14.6 \\
\hline Precipitation $\left(\mathrm{mm} \mathrm{d}^{-1}\right)$ & PP & 0.35 & 13.9 \\
\hline Sunshine duration (h) & Sun & 0.55 & 13.4 \\
\hline Mean air temperature $\left({ }^{\circ} \mathrm{C}\right)$ & $T_{\text {air }}$ & 0.60 & 13.3 \\
\hline Iron $\left(\mathrm{mg}^{-1}\right)$ & $\mathrm{Fe}$ & 0.35 & 13.2 \\
\hline Water temperature $\left({ }^{\circ} \mathrm{C}\right)$ & $T_{\text {water }}$ & 0.55 & 12.6 \\
\hline Redox potential (mV) & redox & 0.45 & 12.6 \\
\hline Total phosphorus (mg l${ }^{-1}$ ) & TP & 0.65 & 12.4 \\
\hline Total organic carbon $\left(\mathrm{mg} \mathrm{l}^{-1}\right)$ & TOC & 0.70 & 12.1 \\
\hline Total nitrogen $\left(\mathrm{mg} \mathrm{l}^{-1}\right)$ & $\mathrm{TN}$ & 0.60 & 11.4 \\
\hline Phaeopigment a $665 \mathrm{~nm}\left(\mu \mathrm{g}^{-1}\right)$ & phae A & 0.60 & 10.3 \\
\hline Ortho-phosphate (mg 1 ${ }^{-1}$ ) & $\mathrm{PO}_{4}{ }^{3-}$ & 0.65 & 10.7 \\
\hline Transparency $(\mathrm{m})$ & transp & 0.85 & 10.0 \\
\hline $\mathrm{pH}$ & $\mathrm{pH}$ & 0.80 & 9.4 \\
\hline Biochemical oxygen demand $\left(\mathrm{mg}^{-1}\right)$ & BOD & 0.61 & 8.7 \\
\hline Silica $\left(\mathrm{mg} \mathrm{l}^{-1}\right)$ & $\mathrm{Si}$ & 0.80 & 8.5 \\
\hline Chlorophyll a $665 \mathrm{~nm}\left(\mu \mathrm{g} \mathrm{l}^{-1}\right)$ & chl A & 0.90 & 6.9 \\
\hline
\end{tabular}

this parameter was strongly correlated with TP (Fig. 3), but explained considerably less variance in the diatom assemblages (Table 2).

These environmental data together explained $70 \%$ of the total variance in the seasonal distribution of diatoms in the sediment trap samples. The CCA revealed a typical seasonal succession of diatoms during the two years of sedimentation captured by the sediment traps (Fig. 5). Diatom assemblages deposited during winter and springs showed negative scores on the first CCA axis and were dominated by Stephanodiscus spp. Environmental conditions during these seasons were characterized by relatively low air and water temperatures, low precipitation, and high TP concentration. During the summer months diatom assemblages generally had high scores on the first CCA axis and were dominated by Fragilaria crotonensis, Epithemia sorex, and F. tenera. Environmental conditions in summer were characterized by high temperatures, precipitation, and $\mathrm{pH}$ and low $\mathrm{TP}$ concentrations. In late summer and autumn Nitzschia paleacea, N. dissipata, F. capucina, and F. delicatissima dominated the assemblages. In contrast to assemblages deposited in early summer these late summer and autumn assemblages were characterized by negative scores on the second CCA axis.

Seasonal diatom variability

The two autumn periods, October 15-December 18 2003 and August 31-November 24 2004, were characterized by intermediate values of TP $(0.04$ $\left.0.06 \mathrm{mg} \mathrm{l}^{-1}\right), \mathrm{pH}(8.0-8.2)$, and temperatures $\left(T_{\text {air }}\right.$ : $4-10^{\circ} \mathrm{C}$; $T_{\text {water }}: 8-14^{\circ} \mathrm{C}$ ). Nitzschia spp., Fragilaria spp., and Stephanodiscus spp. all showed relatively low AR and represented a typical diatom community for these periods (Fig. 4). The relatively low AR of these taxa are likely due to the decreased nutrient concentration and light intensity.

The winter periods, December 18-April 12004 and November 25-April 6 2005, were characterized by high TP $\left(0.10-0.14 \mathrm{mg} \mathrm{l}^{-1}\right)$ and $\mathrm{Ca}$ (54$\left.55 \mathrm{mg} \mathrm{l}^{-1}\right)$ concentrations but low PP (1.3$\left.1.4 \mathrm{~mm} \mathrm{~d}^{-1}\right), \mathrm{pH}(7.3-7.6)$, and temperatures $\left(T_{\text {air }}\right.$ : $<2^{\circ} \mathrm{C}$ and $T_{\text {water }}: 3-4^{\circ} \mathrm{C}$ ). During winter, the AR of the cold-water and eutrophic Stephanodiscus species increased, with Nitzschia spp. and Fragilaria spp. also being present. In Sacrower See, high AR of $S$. 


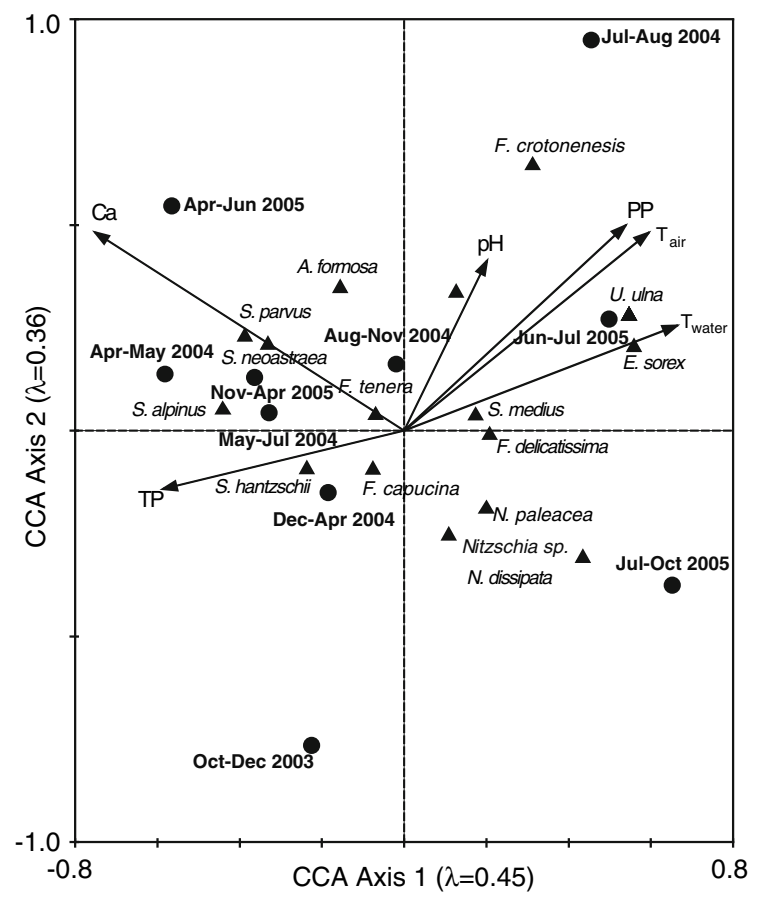

Fig. 5 Tri-plot of a CCA of diatom assemblages in the sediment traps, and of selected environmental parameters. Water and air temperature $\left(T_{\text {air }}, T_{\text {water }}\right)$, precipitation $(\mathrm{PP}), \mathrm{pH}$, dissolved calcium $(\mathrm{Ca})$, and total phosphorus (TP) were included in the CCA. See Fig. 2 for interannual and seasonal variability of these parameters

hantzschii was concurrent with TP concentrations of $\sim 0.14 \mathrm{mg} \mathrm{l}^{-1}$ and temperatures of $\sim 3^{\circ} \mathrm{C}$. During this period, the lake was inversely stratified. Observations of Håkansson \& Stoermer (1984), who found S. hantzschii blooming in spring at temperatures between 4 and $10^{\circ} \mathrm{C}$ and at increased nutrient concentrations, are in agreement with our data. The co-occurrence of $S$. hantzschii with other species of this genus that are typical for winter and spring conditions can also be seen in the CCA (Fig. 5).

Stephanodiscus spp. showed maximum AR during the two spring periods, April 1-May 262004 and April 6-June 8 2005, which were characterized by relatively high TP $\left(0.08-0.1 \mathrm{mg} \mathrm{l}^{-1}\right)$, high $\mathrm{pH}(8.5-$ 9), and $\mathrm{Ca}\left(54-58 \mathrm{mg} \mathrm{l}^{-1}\right)$ and intermediate temperatures $\left(T_{\text {air: }}: 11-13^{\circ} \mathrm{C}, T_{\text {water: }} 11-12^{\circ} \mathrm{C}\right)$. In April and May 2004, S. parvus, S. neoastraea, and S. alpinus had AR of 32,6 , and $20 \times 10^{6}$ valves $\mathrm{m}^{-2} \mathrm{~d}^{-1}$, respectively. During spring 2005, the dominant diatom was $S$. parvus which was accompanied by high AR of $S$. neoastraea, thus showing the same signature as in the previous spring. Fragilaria spp. and Nitzschia spp. had reduced AR (Fig. 4).

In early spring temperatures begin to increase, whereas nutrient concentrations are still high as a consequence of the winter circulation period. These conditions seem to have led to blooms of Stephanodiscus spp. in Sacrower See. Similar observations have been made by Håkansson \& Kling (1989) and Hickel \& Håkansson (1993), who report Stephanodiscus spp. mainly blooming in winter and spring due to lake-water mixing, high nutrient concentrations, and increasing insolation.

Four sediment trap intervals represented the summer periods in our data set: May 26-July 15 2004, July 15-August 31 2004, June 9-July 27 2005, and July 28-October 17 2005. The summer periods were characterized by low TP $\left(0.01-0.05 \mathrm{mg} \mathrm{l}^{-1}\right)$ and $\mathrm{Ca}$ (48-59 $\left.\mathrm{mg} \mathrm{l}^{-1}\right)$. In contrast, $\mathrm{pH}(8.5-8.7)$, precipitation $\left(2.6-2.8 \mathrm{~mm} \mathrm{~d}^{-1}\right)$, and temperatures $\left(T_{\text {air }}: 19-\right.$ $20^{\circ} \mathrm{C} ; T_{\text {water }}: 17-18^{\circ} \mathrm{C}$ ) were high. Stephanodiscus alpinus had the highest $\mathrm{AR}\left(35 \times 10^{6}\right.$ valves $\mathrm{m}^{-2} \mathrm{~d}^{-1}$ ) from the end of May until mid-July 2004. After this period, AR of Stephanodiscus spp. decreased but Nitzschia spp., Fragilaria spp., and E. sorex increased in both numbers and diversity. The last Stephanodiscus occurring in Sacrower See in spring and early summer is Stephanodiscus medius. The increased AR of $S$. medius may be interpreted as being indicative of increased temperatures (Kienel et al., 2005). This is supported by the CCA which places $S$. medius into the group of diatoms characteristic for the summer periods (Fig. 5).

During spring and summer the primary production increases, causing reduced concentrations of dissolved $\mathrm{CO}_{2}$ and, consequently, increased $\mathrm{pH}$ values. Together with low concentration of phosphates in the water, this triggers calcite precipitation in hardwater lakes, usually in late spring as soon as $\mathrm{PO}_{4}{ }^{3-}$ concentrations decrease. This calcite precipitation is indicated in Sacrower See by decreased concentrations of dissolved Ca (Fig. 2). CCA and PCA showed that $\mathrm{Ca}$ concentration was not strongly correlated to seasonal changes in $\mathrm{pH}$. It is known from other studies that calcite formation is not only dependent on $\mathrm{pH}$ but also on the occurrence of algae such as Stephanodiscus spp., Asterionella formosa, F. crotonensis, Phacotus lenticularis, which form heterogeneous nuclei for calcite precipitation (e.g. 
Stabel, 1986). These algae were also found in the summer sediment traps of Sacrower See.

During summer 2004, high water temperatures of $\sim 18^{\circ} \mathrm{C}$ and reduced TP concentrations of $\leq 0.01 \mathrm{mg} \mathrm{l}^{-1}$ most likely initiated the dominance of $F$. crotonensis and the occurrence of A. formosa. A similar diatom composition is observed in the summer plankton of the shallow, polymictic Grimnitzsee, Germany (Gervais et al., 1999). According to Kilham (1986), the dominance of these two diatom species requires a low concentration of nutrients and a stratified water column. Moreover, the observed high accumulation rates indicate that $F$. crotonensis might not have been influenced by grazing, which affects mainly smaller diatoms and green algae (Sommer, 1986). The dominance of $F$. crotonensis coincides with reduced $\mathrm{pH}$ values and nutrient depletion of the water column. The highest concentration of this species appeared together with the highest recorded temperature $\left(18.2^{\circ} \mathrm{C}\right)$ for the summer of 2004 .

Interannual diatom variability

$T_{\text {air }}, T_{\text {water }}$, TP, and $\mathrm{pH}$ showed distinct differences between the two observed seasonal cycles. TP was $\sim 0.06 \mathrm{mg} \mathrm{l}^{-1}$ in autumn 2003 compared to $\sim 0.03 \mathrm{mg} \mathrm{l}^{-1}$ in autumn 2004 and both water and air temperatures in autumn $2003\left(T_{\text {water }}: 9.4^{\circ} \mathrm{C}\right.$ and $T_{\text {air }}: 4.3^{\circ} \mathrm{C}$ ) were lower than in autumn 2004 ( $T_{\text {water }}$ : $13.1^{\circ} \mathrm{C}$ and $T_{\text {air }}: 10.1^{\circ} \mathrm{C}$ ) (Fig. 2). Increased AR and numbers of species were mainly recorded in the periphyton and tychoplankton (Fragilaria spp. and Nitzschia spp.) in autumn 2004. In addition, more Stephanodiscus spp. occurred in autumn 2004 in comparison to 2003 when only S. hantzschii and $S$. alpinus had reasonably high AR. Higher temperatures in autumn 2004 could be a reason for the increased diversity of benthic diatoms.

Mean TP concentrations were higher in winter 2003/2004 $\left(\sim 0.14 \mathrm{mg} \mathrm{l}^{-1}\right)$ than in winter 2004/2005 $\left(\sim 0.1 \mathrm{mg} \mathrm{l}^{-1}\right)$, whereas the other water chemistry and climate parameters had similar values. Hence, TP was possibly a controlling factor for diatom assemblages. Higher concentrations of TP in winter 2004 may have led to a more intense growth of Stephanodiscus spp. and especially tychoplankton (e.g. Fragilaria spp. and Nitzschia spp.).

The timing of the peak occurrence of S. alpinus differed in the two study years, with maximum values observed between May and July in 2004 and between November 2004 and April in 2005 (Fig. 4). Although there were some differences in the exposure dates of the sediment traps between the two study years, traps were changed at almost the identical date during early spring (April 1, 2004 and April 6, 2005). Possibly, the difference in maximum growth of $S$. alpinus is related to the earlier onset of the growing season in 2005 compared with 2004. Air temperatures increased at a similar date in 2004 and 2005 (mid-March; Fig. 2). However, in 2004, this initial increase in temperature was followed by a period of cooler temperatures in the second half of March and early April. This probably affected the spring water temperatures as well, although water temperature data are not available at a high enough temporal resolution to confirm this. In Plußsee (Germany), S. alpinus appeared at water temperatures between 1.9 and $9.6^{\circ} \mathrm{C}$ (Hickel \& Håkansson, 1993). It has also been reported to occur during summer at water temperatures of $14-15^{\circ} \mathrm{C}$ and water transparency of up to $8 \mathrm{~m}$ (Genkal, 1993).

TP concentrations were also higher in spring 2004 $\left(\sim 0.1 \mathrm{mg} \mathrm{l}^{-1}\right) \quad$ in comparison to 2005 $\left(\sim 0.07 \mathrm{mg}^{-1}\right)$. In contrast, mean $\mathrm{pH}$ exhibited higher values in 2005. As a consequence, thermal stratification of the water column may have been less stable early in the spring of 2004 than in 2005. In Lake Constance the phytoplankton is highly dependant on slight temperature changes during the onset of stratification, as well as on the transition from strong mixing in the cold seasons to the weak mixing in lake waters in spring (Peeters et al., 2007a, b). Differences in the onset of summer stratification in 2004 and 2005 may have influenced the diatom assemblages at Sacrower See as well, and together with higher TP concentrations in spring 2004, this may have led to higher diversity and AR of Stephanodiscus spp.

In addition, there was a shift of the starting date for the increase in $\mathrm{pH}$ during spring and summer in 2005 compared with 2004. In spring 2004 this increase started in April, whereas in 2005 the first increase in pH occurred already in March (Fig. 2). High primary productivity leads to increased $\mathrm{pH}$ values in the epilimnion (Wetzel, 2001). Therefore, the difference in the starting date of the $\mathrm{pH}$ increase in Sacrower See is indicative of an earlier onset of the spring phytoplankton bloom in 2005 compared to 2004 . Hausmann \& Pienitz (2007) point out that a short-term $\mathrm{pH}$ shift could also be a consequence of increased 
primary production in response to favourable hydrological conditions.

The differences in the onset of the spring temperature rise and summer stratification are also visible in the CCA (Fig. 5), where the diatom sample of the spring 2005 period is not grouped with the species generally found in cold periods of the year. In contrast, the diatom assemblages of spring and early summer 2004 are grouped with assemblages deposited in late autumn and winter. A relationship of diatom assemblages with stratification dynamics was also found in sediment trap samples of Bates Pond, Connecticut (USA) (Köster \& Pienitz, 2006).

Higher TP concentrations $\left(\sim 0.05 \mathrm{mg} \mathrm{l}^{-1}\right)$ were measured in summer 2005 than in summer 2004 ( $\sim 0.03 \mathrm{mg} \mathrm{l}^{-1}$ ). Furthermore, the diatom growing season was also longer in 2005, due to the longer duration of high temperatures, hence many periphytic diatoms showed increased diversity and AR. Also, at the end of summer $2005 \mathrm{pH}$ and temperatures were higher and Ca lower than in 2004, which could explain the higher diversity and AR of periphytic and tychoplanktonic diatoms. TP concentrations were still relatively high in late summer 2005 (Fig. 2). The relatively high $\mathrm{pH}$ values during this period suggest that as a consequence primary production may have been higher in late summer 2005 than in 2004. Warmer temperatures may extend summer stratification and benthic diatom blooms may thus last longer (Round, 1981). Model results of Peeters et al. (2007a) for Lake Constance showed that an increase in air temperature during the late summer leads to a reduced duration of homothermy and thus to an increase in the duration of the stratification period. Our results showed that in Sacrower See benthic diatoms reacted strongly to increased water temperatures in late summer 2005 by increased AR. In comparison, during the same period of the first year of sampling, air and water temperature, $\mathrm{pH}$, and TP had lower values and the AR of benthic diatoms were low with many benthic species found in 2005 not being present at all.

\section{Conclusions}

Physical and chemical parameters and diatom assemblages showed a distinct seasonal variability in Sacrower See. The autumn and summer diatom assemblages were characterized by Nitzschia spp.,
Stephanodiscus spp., and Fragilaria spp., whereas the winter and spring assemblages were represented by planktonic diatoms mainly of the genus Stephanodiscus.

This study indicates that in Sacrower See the interannual diatom variability may be affected by comparatively small changes in TP concentrations and water temperature. During autumn, winter, and spring the diatom flora in Sacrower See seems to be controlled mainly by the availability of nutrients, the onset of the growing season, and lake water stratification. During summer and early autumn, the sedimentation and diversity of benthic diatoms seems to be influenced by the length of stratification, nutrient concentrations and water temperature during the stratification period.

The results provide detailed information on the succession of diatoms in Sacrower See during the seasonal cycle and on the effects of temperature, nutrients, and growing season length on the lake's diatom assemblages. These observations therefore provide important baseline data to interpret fossil diatom assemblages in the lake's sediments, especially in respect to changes in the onset and length of summer stratification and winter circulation, and to past diatom productivity during these periods.

Acknowledgments We would like to thank Dirk Enters, Torsten Haberzettl, Britta Lüder, and Michael Fey for their help during fieldwork. Hermann Oesterle is acknowledged for providing the data of the meteorological station at PotsdamTelegrafenberg. We are much obliged to Herbert Ebel, Uwe Brämick, Frank Rümmler, and Steffen Zienert from the Institut für Binnenfischerei Potsdam for their support during fieldwork and for providing local infrastructure. We acknowledge the Landesumweltamt Brandenburg for providing data on the physical and chemical properties of the lake water. This study was supported from grant DFG Zo 102/4-1 by the German Science Foundation, the Central Research Supply (Zentrale Forschungsförderung) by the University of Bremen (08/141/2), and the Utrecht Centre of Geosciences. This is Netherlands Research School of Sedimentary Geology (NSG) publication no. 20080502.

Open Access This article is distributed under the terms of the Creative Commons Attribution Noncommercial License which permits any noncommercial use, distribution, and reproduction in any medium, provided the original author(s) and source are credited.

\section{References}

Anderson, N. J., 2000. Diatoms, temperature and climatic change. European Journal of Phycology 35: 307-314. 
Battarbee, R. W., 1973. A new method for estimation of absolute microfossil numbers, with reference especially to diatoms. Limnology and Oceanography 18: 647-653.

Battarbee, R. E., V. J. Jones, R. J. Flower, N. J. Cameron, H. Bennion, L. Carvalho \& S. Juggins, 2001. Diatoms as indicators of surface water acidity. In Smol, J. P., H. J. B. Birks \& W. M. Last (eds), Tracking Environmental Changes Using Lake Sediments: Terrestrial, Algal, and Siliceous Indicators, Vol. 3. Kluwer Academic Publishers, The Netherlands: 155-203.

Battarbee, R. E., N. J. Anderson, E. Jeppesen \& P. R. Leavitt, 2005. Combining palaeolimnological and limnological approaches in assessing lake ecosystem response to nutrient reduction. Freshwater Biology 50: 1772-1780.

Bennion, H. \& R. Battarbee, 2007. The European Union Water Framework Directive: opportunities for palaeolimnology. Journal of Paleolimnology 38: 285-295.

Birks, H. J. B., V. J. Jones \& N. L. Rose, 2004. Recent environmental changes and atmospheric contamination on Svalbard as recorded in lake sediments-synthesis and general conclusions. Journal of Paleolimnology 31: 532-546.

Blass, A., M. Grosjean, A. Troxler \& M. Sturm, 2007. How stable are twentieth-century calibration models? A highresolution summer temperature reconstruction for the eastern Swiss Alps back to AD 1580 derived from proglacial varved sediments. The Holocene 17: 51-63.

Bluszcz, P., E. Kirilova, A. F. Lotter, C. Ohlendorf \& B. Zolitschka, 2008. Global radiation and onset of stratification as forcing factors of seasonal carbonate and organic matter flux dynamics in a hypertrophic hardwater lake (Sacrower See, Northeastern Germany). Aquatic Geochemistry 14: 73-98.

Compère, P., 2001. Ulnaria (Kützing) Compère, a new genus name for Fragilaria subgen. Alterasynedra Lange-Bertalot with comments on the typifiction of Synedra Ehrenberg. In Jahn, R., J. P. Kociolek, A. Witkowski \& P. Compère (eds), Studies on Diatoms. Ganter, Ruggell: 417-432.

Clarke, G., M. Kernan, A. Marchetto, S. Sorvari \& J. Catalan, 2005. Using diatoms to assess geographical patterns of change in high-altitude European lakes from pre-industrial times to present day. Aquatic Sciences 67: 224-236.

Genkal, S. I., 1993. Large-celled, undulate species of the genus Stephanodiscus Ehr. in USSR reservoirs: morphology, ecology and distribution. Diatom Research 8: 45-64.

Gervais, F., S. Berger, I. Schöenfelder \& R. Rusche, 1999. Basic limnological characteristics of the shallow eutrophic lake Grimnitzsee (Brandenburg, Germany). Limnologica 29: 105-119.

Håkansson, H., 2002. A compilation and evolution of species in the genera Stephanodiscus, Cyclostephanos and Cyclotella with a new genus in the family Stephanodiscaceae. Diatom Research 17: 1-139.

Håkansson, H. \& H. Kling, 1989. A light and electron microscope study of previously described and new Stephanodiscus species (Bacillariophyceae) from central and northern Canadian lakes, with ecological notes on the species. Diatom Research 4: 269-288.

Håkansson, H. \& E. F. Stoermer, 1984. Observations on the type material of Stephanodiscus hantzschii Grunow in Cleve \& Grunow. Nova Hedwigia 39: 477-495.
Hall, R. I., P. R. Leavitt, R. Quinlan, A. S. Dixit \& J. P. Smol, 1999. Effects of agriculture, urbanization, and climate on water quality in the northern Great Plains. Limnology and Oceanography 44: 739-756.

Hausmann, S. \& R. Pienitz, 2007. Seasonal climate inferences from high resolution modern diatom data along a climate gradient. Journal of Paleolimnology 38: 73-96.

Hickel, B. \& H. Håkansson, 1993. Stephanodiscus alpinus in Plusssee, Germany. Ecology, morphology and taxonomy in combination with initial cells. Diatom Research 8: 8998.

Kienel, U., M. J. Schwab \& G. Schettler, 2005. Distinguishing climatic from direct anthropogenic influences during the past 400 years in varved sediments from Lake Holzmaar (Eifel, Germany). Journal of Paleolimnology 33: 327-347.

Kilham, S. S., 1986. Dynamics of Lake Michigan natural phytoplankton communities in continuous cultures along a Si:P loading gradient. Canadian Journal of Fisheries and Aquatic Sciences 43: 351-360.

Kilham, S. S., E. C. Theriot \& S. C. Fritz, 1996. Linking planktonic diatoms and climate in the large lakes of the Yellowstone ecosystem using resource theory. Limnology and Oceanography 41: 1052-1062.

Köster, K. \& R. Pienitz, 2006. Seasonal diatom variability and paleolimnological inferences-a case study. Journal of Paleolimnology 35: 395-416.

Krammer, K. \& H. Lange-Bertalot, 1991. Bacillariophyceae 4. Teil: Achnanthaceae. In Ettl, H., G. Gärtner, J. Gerloff, H. Heynig \& D. Mollenhauer (eds), Süßwasserflora von Mitteleuropa, Band 2/4. Gustav Fischer Verlag, Heidelberg: $437 \mathrm{pp}$

Krammer, K. \& H. Lange-Bertalot, 1999a. Bacillariophyceae 1. Teil: Naviculaceae. In Ettl, H., J. Gerloff, H. Heynig \& D. Mollenhauer (eds), Süßwasserflora von Mitteleuropa, Band 2/1. Gustav Fischer Verlag, Heidelberg: 876 pp

Krammer, K. \& H. Lange-Bertalot, 1999b. Bacillariophyceae 2. Teil: Bacillariaceae, Epithemiaceae, Surirellaceae. In Ettl, H., J. Gerloff, H. Heynig \& D. Mollenhauer (eds), Süßwasserflora von Mitteleuropa, Band 2/2. Gustav Fischer Verlag, Heidelberg: $611 \mathrm{pp}$

Krammer, K. \& H. Lange-Bertalot, 2000. Bacillariophyceae 3. Teil: Centrales, Fragilariaceae, Eunotiaceae. In Ettl, H., G. Gärtner, J. Gerloff, H. Heynig \& D. Mollenhauer (eds), Süßwasserflora von Mitteleuropa, Band 2/3. Gustav Fischer Verlag, Heidelberg: 599 pp.

Livingstone, D. M. \& A. F. Lotter, 1998. The relationship between air and water temperatures in lakes of the Swiss Plateau: a case study with palaeolimnological implications. Journal of Paleolimnology 19: 181-198.

Lotter, A. F. \& C. Bigler, 2000. Do diatoms in the Swiss Alps reflect the length of ice-cover? Aquatic Sciences 62: 125141.

Lotter, A. F. \& H. J. B. Birks, 1997. The separation of the influence of nutrients and climate on the varve time-series of Baldeggersee, Switzerland. Aquatic Sciences 59: 362375.

Lüder, B., G. Kirchner, A. Lücke \& B. Zolitschka, 2006. Palaeoenvironmental reconstructions based on geochemical parameters from annually laminated sediments of Sacrower See (northeastern Germany) since the 17th century. Journal of Paleolimnology 35: 897-912. 
Menzel, A., G. Jakobi, R. Ahas, H. Scheifinger \& N. Estrella, 2003. Variations of the climatological growing season (1951-2000) in Germany compared with other countries. International Journal of Climatology 23: 793-821.

Peeters, F., D. Straile, A. Lorke \& D. Livingstone, 2007a. Earlier onset of the spring phytoplankton bloom in lakes of the temperate zone in a warmer climate. Global Change Biology 13: 1898-1909.

Peeters, F., D. Straile, A. Lorke \& D. Ollinger, 2007b. Turbulent mixing and phytoplankton spring bloom development in a deep lake. Limnology and Oceanography 51: 286-298.

Raubitschek, S., A. Lücke \& G. H. Schleser, 1999. Sedimentation patterns of diatoms in Lake Holzmaar, Germany - (on the transfer of climate signals to biogenic silica oxygen isotope proxies). Journal of Paleolimnology 21: 437-448.

Round, F. E., 1981. The Ecology of Algae. Cambridge, Cambridge University Press: $653 \mathrm{pp}$

Round, F. E., R. Crawford \& D. Mann, 1990. The Diatoms. Biology and Morphology of the Genera. Cambridge University Press, Cambridge: 747.

Schönfelder, I., J. Gelbrecht, J. Schöenfelder \& C. E. W. Steinberg, 2002. Relationships between littoral diatoms and their chemical environment in northeastern Germany lakes and rivers. Journal of Phycology 38: 66-82.

Sommer, U., 1986. The periodicity of phytoplankton in Lake Constance (Bodensee) in comparison to other deep lakes of central Europe. Hydrobiologia 138: 1-7.

Stabel, H.-H., 1986. Calcite precipitation in Lake Constance: Chemical equilibrium, sedimentation, and nucleation by algae. Limnlogy and Oceanography 31: 1081-1093.

Stoermer, E. F., 1993. Evaluating diatom succession peculiarities of the Great Lakes case. Journal of Paleolimnology 8: 71-83.

Stoermer, E. F. \& J. P. Smol, 1999. The Diatoms: Applications for Environmental and Earth Sciences. Cambridge University Press, Cambridge: 469 pp.

Ter Braak, C. J. F. \& P. Šmilauer, 1998. CANOCO Reference Manual and User's Guide to CANOCO for Windows: Software for Canonical Community Ordination (version 4). Microcomputer Power Ithaca, NY: 351 pp.

Wetzel, R. G., 2001. Limnology. Academic Press, San Diego: $1006 \mathrm{pp}$.

Zolitschka, B., 2003. Dating based on freshwater- and marinelaminated sediments. In Mackay, A., R. Battarbee, J. Birks \& F. Oldfield (eds), Global Change in the Holocene. Arnold, London: 92-106. 